\title{
ARAŞTIRMA MAKALESI
}

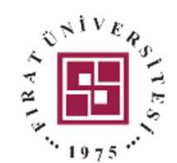

Frrat Üniversitesi Sosyal Bilimler Dergisi

The Journal of International Social Sciences

Cilt: 28, Sayı: 2, Sayfa: 109-124, TEMMUZ - 2018

Makale Gönderme Tarihi: 05.06.2018 Kabul Tarihi: 02.07.2018

\section{REFIK HALID KARAY'IN ORTADOĞU ILLE ILGILİ YAZILARI ${ }^{1}$}

\author{
Writings On Middle East Of Refik Halid Karay \\ Muhammed HÜKÜM²
}

Öz

Refik Halid Karay, Türk hikâye ve romanında önemli bir yere sahip olmasının yanında siyasi ve sosyal içerikli gazete yazıları ile tanınan bir yazardır. Refik Halid Karay, siyasi tavrı sebebi ile iki kez sürgün hayatı yaşamıştır. Yazarın ilk sürgünlüğ̈̈ 1913 'te başlayarak 1918'de biter. Refik Halid'in ikinci sürgünü ise 1922'de Beyrut'ta başlar ve 1938 'de sona erer. Özellikle Ortadoğu'da geçen ikinci sürgün dönemi onun edebi kimliğgi üzerinde etkili olmuştur. Sürgün romanı ve Gurbet Hikâyeleri Ortadoğu'da yaşadığı sürgünlük deneyimini odağa alan eserlerdir.

Refik Halid'in Memleket Yazıları serisinin 17. kitabı "Sulhte Cimri, Harpte Müsrif” yazarın özellikle Suriye, Lübnan, Kıbrıs, Hatay gibi Ortadoğu coğrafyasının önemli merkezleri hakkında yaptığı siyasi ve sosyal tahlilleri içerir. Bu yazılar dünya siyaseti ve Osmanlı sonrası Ortadoğu'nun sosyal ve siyasi yapısını göstermesi açısından önemli yazılardır.

Anahtar Sözcükler: Refik Halid Karay, Ortadoğu, Dünya Siyaseti

\section{ABSTRACT}

Refik Halid Karay is a well-known writer with his political and social contented newspaper articles as well as having an important place in Turkish story and novels. Refik Halid Karay was exiled two times because of his political attitude. First exile of the writer started in 1913 and ended in 1918. Second exile of Refik Halid started in Beirut in 1922 and ended in 1938. Especially the second exile period lasted in Middle east effected the literary identity of him. His Sürgün [Exile] novel and Gurbet Hikâyeleri [Abroad Stories] are the works focusing on his exile experience in Middle East.

17th book of Memleket Yazıları [Hometown Writings] series named "Sulhte Cimri, Harpte Müsrif [Mean at Peace, Wasteful at War]" of Refik Halid contains political and social analysis about important centers of Middle East geography such as especially Syria, Lebanon, Cyprus, Hatay. These writings are important writings in that they reflect the political and social structure of Middle East after world politics and Ottoman.

Keywords: Refik Halid Karay, Middle East, World Politics

\section{Refik Halid'in Orta Doğu ile İlişkisisi, Edebî Dünyası ve Gazeteciliği}

Gazeteci, mizah yazarı, hikâyeci ve romancı olarak tanınan Refik Hâlid, (1888-1965) başlangıçta Fecr-i Âti topluluğu içinde yer almakla beraber, bilhassa 1917'den itibaren Millî Edebiyat Hareketi'ne katılarak ölünceye kadar bu hareketin ruhuna uygun yazılar yazar. Refik Halid Karay, çok çeşitli konu ve türlerde yazdığı yazılarıyla son devir edebiyatımızın en popüler yazarları arasında yer alır. Batıya açık, kültürlü ve yenilik taraftarı, maddî imkânları iyi olan bir aile ortamında yetişen Refik Hâlid, istikrarlı bir öğrenim görmemiştir. 1900-1906 yılları arasında Galatasaray Lisesi' ne devam ettiyse de burayı bitirememiştir. 1907'de Hukuk Fakültesi'ne geçmiş, bir ara Maliye'de memurluk yapmış, 1908 Meşrutiyetinin ilânı üzerine de okulu ve memurluğu bırakarak tamamıla yazı hayatına atılmıştır (Özbalcı, 1988: 77).

\footnotetext{
${ }^{1}$ Bu makale 26-27 Ekim 2017 Tarihinde Kilis 7 Aralık Üniversitesi’nde düzenlenen “Uluslararası Mercidabık’tan Günümüze 500 Yılda Ortadoğu Sempozyumu”nda sunulmuş sözlü bildirinin genişletilmiş ve yeniden düzenlenmiş halidir. Tam metin başka hiçbir yerde yayınlanmamıştır.

${ }^{2}$ Dr. Öğr. Üyesi, Kilis 7 Aralı Üniversitesi, KİLİS e-posta; mhukum@kilis.edu.tr
} 


\section{F.Ü. Sosyal Bilimler Dergisi 2018-28/2}

Refik Halid'i bir gazete yazarı olarak da bir romancı olarak farklı bir konuma taşıyan ne siyasî görüşleri ne muhalifliğidir. Onun Türk edebiyatına kazandırdığı en özgün niteliklerden biri gazete yazılarında ve kurgusal metinlerinde kullandığı dildir. Refik Halid Karay'ın kullandığı dil, Türk edebiyatında gazete yazısı, öykü ve roman formlarında, özgün ve çok geniş ifade kabiliyetine sahip bir özellik taşır. Cemil Meriç'in "Bayağılığa düşmeden tabii, taze, samimi ve kaynaktan fişkıran su gibi berrak" (Meriç, 1998:267) sıfatları ile ifade ettiği bu tarzın, dönemin edebî dili için oldukça ufuk açıcı olduğunu belirtmek gerekir. Başta gazete yazıları olmak üzere Karay’ın yazdığı yazılar bir sohbet havasında kaleme alınmış, kendinden bir şeyler katarak ilerleyen, konuşmalarla süslenen, hatıralarla zenginleştirilen yazılardır. Kısa ama eğlendiren; hayata, yaşanılan çevreye ait gözlemlerle beslenen düşünceler; öğretmeyen, uyarmayan, öfkelenmeyen bir dille kaleme alınmışlardır. Refik Halid'i farklı kılan, onu üslup sahibi yapan yönü de burasıdır. Küçük dikkatler, hayata ait çağrışımlar, ilginç benzetmeler (Törenek, 2013: 163) yazıların akıcılığını ve okunabilirliğini sağlayan temel yönelimlerdir.

$\mathrm{Bu}$ açıdan bakıldığında Refik Halid'in Türkçe ile ilgili kat'i ve vazgeçilmez bir üslup sahibi olduğu gözlemlenebilir. Refik Halid'in dil konusundaki özgünlüğü ve yeteneği yazarlık sürecini başlatan ve etkileyen bir olaylar dizgesi üzerinden anlaşılabilir. Refik Halid Karay, Meşrutiyet sonrasında Cem gazetesinde bir yazı yazar ve yazı çok büyük bir ilgi görür. Bu mecmuada Refik Halid yine daha önce hiç yapılmamış bir şey yaparak "Tarih-i Devr-i Mebusan" ve "Kirpi-i Natüvan" imzasıyla Naima üslubuyla "Enderun Edebiyatı" nesrinin tüm özelliklerini gösteren bir dizi mizahî yazı kaleme alır. Bu yazılarla eski nesri mükemmel Arapça bilgisiyle mizah alanında uygular; ancak yazıları okuyanlar bunların 23 yaşında genç bir muharririn kaleminden çıkmış olabileceğine inanmazlar. Yazıların Refik Halid'in olduğu daha sonra anlaşılır. Böylece bir çığır açmış olan yazarın arkasından aynı yöntemle yazanlar olmuştur (Ebcioğlu, 1943). "Kirpi" adıyla yazmaya Şehrah'ta devam eder ve yazdıkları sürekli olarak ses getirir. "Kirpi" adıyla yazılan yazılar 1911'de Kirpinin Dedikleri adlı bir kitapta toplanır.

Eşref, Şehrah, Kalem ve Cem dergilerinde imzasız veya "Kirpi" takma adıyla yayımladı̆̆ siyasi yazı ve hicivlerinden dolayı tedirgin olan İttihat ve Terakki iktidarı, Mahmud Şevket Paşa'nın katli ile suçlananlar arasında onu da Sinop'a (1913) arkasından Çorum'a (1916) sürgün eder. Bu sürgün kendi isteğiyle önce Ankara'ya (1917) daha sonra Bilecik'e (1917-1918) çevrilir. Refik Halid Karay, "Millî Mücadele aleyhine yazdıkları sebebiyle cezalandırılacağından korkup 1922'de yurdu terk ettikten sonra, 16 y1l Beyrut, Cünye ve Halep'te yaşar. O y1llarda Halep'te ve Şam'da 2 Türkçe gazete çıkmaktadır: Doğruyol ve Vahdet. Doğruyol'u, 150'liklerden Celâl Kadri ve akrabası Hasan Kadri, Vahdet'i ise Nuri Genç çıkarmaktadır. Vahdet'te Cemil Meriç'in tanıdı̆̆ 1 Tarık Mümtaz (Göztepe) ile Antakya Sultanîsi'nde hocası Ali İlmi Fanî (Bilgili) de yazılarını yayınlamaktadır. Karay da bu gazetelerin yazar kadrosundadır." (Karaca, 2017). Meriç, o yıllarda bir de Şam'da Musavver Sahra adlı Türkçe dergi çıktığını, ayrıca Kuneytire'de yarı Türkçe bir gazete yayımlandığını söyler (Meriç, 1998: 255).

Gazete yazılarındaki muhalif kimliğin onun sürgünlerinin sebebi olduğu düşünüldüğünde Refik Halid'in edebî dünyasını şekillendiren nedenlerin gazetecilik mesleği ile doğrudan ilişkili olduğu söylenebilir. Edebî açıdan bakıldığında Refik Halid'in Türk edebiyatı içerisinde özellikle öykü türünün gerçekçiliğe yönelmesi ve Anadolu'ya açılması konusunda öncü bir konumda olduğunu belirtmek gerekir. Memleket Hikâyeleri ve Gurbet Hikâyeleri tamamıla yazarın sürgün yıllarının gözlem ve değerlendirmelerinin edebî bir dille ve öykü formunda dile getirilmiş şekilleri olarak göze çarpar. Yezidin Kızı, Çete, Yer Altında Dünya Var, Dişi Örümcek ve Sürgün romanları yazarın Ortadoğu'da özellikle Halep ve Beyrut'ta geçirdiği yılların edebî yansımasıdır. Bu romanlarda ve öykülerde de yer yer Ortadoğu özellikle Suriye coğrafyası ile ilgili saptamalarda bulunmuştur:

“Suriye'de gene biliyorum ki, yeni Türk rejimine muhalif ve onun devrilmesini isteyen şekil şekil gruplar vardı. Bunlardan bir kısmı yabancıydı. Kilikya'dan çekilmelerini unutamayan bir kısım subaylar ve onların elemanları... Sonra kuvvetli bir Türkiye'yi Arap birliği için tehlikeli gören nasyonalistler... Daha sonra, ancak Cumhuriyet'in yıkılmasıyla vatanlarına dönebileceklerini 
sanan hanedan üyeleri ve yüzellilikler... Ermeni, Kürd bağımsızlı̆ıını tasarlayan komiteleri de bunlara eklersek Suriye, her türlü düşmanlık hareketine uygun bir geniş meydandı.” (Karay, 2016: 16-17)

Tüm romanlarında görülen egzotizme yönelme, farklı mekânlar, kültürleri tanıma ve tanıtma eğilimi, farklı coğrafyaları farklı özellikleri ile kurguya taşıma gibi tavırlar da sürgünlük yıllarının etkisi ile Karay'ın yazma biçimine sirayet etmiş özellikler olarak kabul edilebilir. Özellikle egzotizm Karay'ın gazete yazıları ile kurgusal eserleri arasındaki ilişkinin en önemli ortak noktalarından biridir. Gazete yazılarında Güney Amerika'dan Kuzey Avrupa'ya kadar birçok ülkenin siyasi yapısı ve bu ülkelerdeki politik tartışmalar üzerinde duran Refik Halid'in romanlarında da geniş bir coğrafya üzerinde zaman zaman egzotizme ulaşacak bir bilgi dünyası vardır. Kavram olarak da egzotizm içeren Yezidilik konusunda yazdığ 1 romanı olan Yezidin Klzl'nda Ortadoğu coğrafyası ve sosyal yapısı ile ilgili ayrıntılı bilgilerin yanı sıra Arjantin'in doğal ve kültürel özelliklerinden uzun uzadıya bahsi, Karay'ın kurgusal yapı ile geniş entelektüel birikimini uzlaştırma gayretini örneklendirir. Bu açıdan bakıldığında gazete yazılarının Karay'ın romanlarındaki uluslararası bakışını sağlayan entelektüel birikimin kaynağı olduğu da tespit edilebilir.

Refik Halit Karay'ın Memleket Hikâyeleri Anadolu insanının mekânı anlamlandırma biçimi üzerinden ilerleyen yerli özelliklerin gözlemlenebileceği bir eserdir. Gurbet hikâyeleri de "Ortadoğu'ya göç eden Türkler, Arapların kültürel tavırları, Osmanlıya bakışları, Ortadoğu coğrafyasındaki İngiliz ajanların faaliyetleri” (Kanter, 2018: 246) gibi konular üzerinde yoğunlaşan bir dikkatin öyküleridir. Bu açıdan Karay'ın Ortadoğu ile ilişkisini hem kurgusal metinlerinde hem de gazete yazılarında görebilmek, onun yazdığ 1 her iki metin türünün de geniş bir arka plan dâhilinde biçimlendiğini söylememize olanak tanır.

Refik Halid Karay, ilk edebî yazılarını Meşrutiyet sonrası kaleme almaya başlamış bir yazardır. Meşrutiyet'in ilanıyla okulu ve memuriyeti bırakarak Servet-i Fünun ve Tercüman-1 Hakikat gazetelerinde çalışmıştır. Bir süre Son Havadis adıyla bir gazete çıkarmıştır (Okay, 2001: 480) Tüm bu süreçten hareketle Karay'ın edebî yazılarının gelişiminin ve üslubunun da gazetecilikle doğrudan ilişkili olduğunu söylemek mümkündür. Önceleri daha çok mizah ve hiciv ağırlıklı siyasî gazete fikraları yazan Refik Hâlid'in, Ayşe'nin Talihi adını taşıyan ilk hikâyesi, 1909 yılında Muhit mecmuasında yayınlanır. Refik Halid, Osmanlı İmparatorluğu'nun yıkılışı, Millî Mücadele dönemi ve Türkiye Cumhuriyeti'nin kuruluşuna hem gazeteci kimliği ile hem de edebiyat sahasında eserler veren bir sanatçı olarak şahitlik etmiştir. Refik Halid'in Ortadoğu ile ilişkisi her iki kimliği üzerinden de okunmaya müsaittir. Zira "Refik Halid Karay, eserlerinde Türkiye dışında meydana gelen tarihî ve siyasi konulara ilgi duyan ve bu konular üzerinde değerlendirmelerde bulunan yazarlardan biridir. Hemen hemen bütün eserlerinde daha önceden yapmış olduğu tarihî araştırmalardan ve yaşadığı dönemle ilgili gözlemlerden istifade etmiştir. Yazarın dünya tarihi ile ilgili olarak üzerinde durduğu konuları genel itibarıyla Amerika tarihi, Güney Amerika tarihi, Avrupa tarihi, Asur, Çerkez, Dürzî ve Yezidî tarihi, Doğulu ve Batılı mütefekkirler, I. ve II. Dünya Savaşları gibi oldukça geniş bir alan nüfuz eden yönelimlerdir. Özellikle ikinci sürgün yıllarında yaşamını sürdürdüğ̈ Lübnan ve Suriye'de yaptı̆̆ı gözlemlerde Arap yarımadasından Arjantin'e yapılan göçler, Osmanlı Devleti'nden ayrıldıktan sonra Arap devletlerinin Türkiye'ye bakışları hakkında yazıları önemli bir kaynak vazifesi de görebilecek metinlerdir (Ünal, 2013: 283-296). Karay'ın Ortadoğu tecrübesi ile üslubuna kattıkları Osmanlı yazı dilinin, geniş bir coğrafyadan elde edilen estetik özellikleriyle birlikte ortaya çıkarılması için de önemli bir veridir.

Millî Mücadele'ye muhalifliği sebebi ile 1 Haziran 1924 tarihli kararnâme ile sürgün edilen, 150'likler olarak anılanlar arasında Refik Halid Karay da vardır. Refik Halid bu kararnamenin çıkmasından önce 9 Ekim 1922'de Türkiye'den ayrılarak Suriye'de Beyrut yakınlarındaki Cünye kasabasına yerleşmiştir. Burada geçimini Doğru Yol ve Vahdet gibi Türkçe gazetelere yazdığ 1 makaleleriyle sağlayan Karay, bu esnada sık sık Halep'te bulunmuştur. Refik Halid'in daha sonra Cumhuriyet inkılaplarını takdir eden yazıları, Hatay'ın Türkiye'ye ilhakı için bölgedeki Türk 


\section{F.Ü. Sosyal Bilimler Dergisi 2018-28/2}

gençlerini teşvik gayretleri Ankara hükümetini memnun ettiğinden önce özel olarak affı söz konusu olmuştur. Bir süre sonra da "Yüzellilikler" hakkında çıkarılan af kanununun yürürlüğe girmesiyle Karay, on altı yıllık sürgün hayatının ardından Temmuz 1938'de Türkiye'ye dönmüştür (Okay, 2001:480-482).

Ölümünde kadar gazete yazıları ve edebî eserler yazmaya devam eden Refik Halid Karay'ın tüm gazete yazıları Memleket Yazıları serisi ismiyle 18 cilt halinde İnkılap Yayınevi tarafindan 2017 yılında tekrar basıldı. Refik Halid'in ülkeye dönüşünden sonra 1938-1965 arasında Tan, Akşam Yeni Istanbul, Zafer gibi gazetelerde yazdığ 1 yazıların bir kısmı Halep ve Beyrut'ta kaldığ1 süredeki gözlemleri ile bu dönemin 1şığında Ortadoğu ve dünya siyasetini yorumladığı yazılardır. Yazılarda dikkate çarpan unsurlar Refik Halid'in Türkçe sevgisi ve hemen her konuya karş1 geliştirdiği ihtiyatlı, yerleşik düzenin devamını önceleyen tavrıdır.

\section{Refik Halid'in Ortadoğu Yazıları, Osmanlı Sonrası Fransız Mandası Altındaki Suriye Yazıları}

Refik Halid Karay, yurda döndükten sonra yazdığı gazete yazılarını daha çok politik eksende yazar. I. Dünya savaşı sonrası dünyadaki gelişmeler ve II. Dünya Savaşı'nın etkileri yoğunlaştığı noktalardır. Ortadoğu ile ilgili yazdığ 1 yazılar 1941'den başlayarak 1958 e kadarki süreçte Tan, Akşam, Yeni Istanbul gazetelerinde fasılalı olarak yazdığı yazılardan oluşur. Yazıların tamamı dikkate alındığında Karay'ın bu coğrafyadaki 16 yıllık tecrübelerinin Doğu-Batı ilişkileri konusunda oldukça büyük bir fikrî olgunlaşma yaşadığı intibaını uyandırdığını söylemek mümkündür. Sürgün öncesinde Batı'nın dünyaya getirdiği cihan ideali fikrine inanan Karay'ın I. Dünya Savaşı ve sonrasında Batı'nın özellikle Ortadoğu'daki politikaları sebebi ile bu ideale olan inancının yerini gerçekçi bir gözlemciliğin aldığını söylemek gerekir. Özellikle Fransızların Suriye'deki politik hamlelerini dikkatle izleyen Karay için bu süreç kendi fikri gelişimi açısından bir öze dönüş yönelimini hissettirir.

1941'den 1958'e kadar olan dönemde yayınlanmış yazılar, I. Dünya Savaşı sonrasından başlayarak Suriye'deki siyasî gelişmeler üzerinden ilerler. I. Dünya Savaşı'ndan sonra Fransız mandası altına giren Suriye 1936'da Fransa'nın kontrolünde bir cumhuriyet olmuş, 1941'de bağımsızlığını ilân etmiştir. Fransa bu kararı 1944'te tanımış ve son yabancı birlik de ülkeyi 1946 Nisan'ında terk etmiştir. 1946'da iş başına gelen ve ailesi aslen Konyalı olan Suriye Cumhurbaşkanı Şükrü el Kuvvetli, 30 Mart 1949'da liderliğini Albay Hüsnü Zaim'in yaptığı bir darbe ile devrilmiştir (Bardakçı, 2011). Yine bu esnada, bir yıllık bağımsızlığın ardından Hatay Meclisi 29 Haziran 1939'da Türkiye'ye katılma kararı almıştır. Bu gelişmeleri takiben, 24 Temmuz'dan sonra Fransız askerleri Hatay'dan çekilmiştir. Bu durum karşısında Refik Halid'in tavrı, Hatay'ın ana vatana katılmasını desteklemek yönünde olmuştur. Affedilerek yurda dönüşünde bu çabaların olumlu etkileri olduğunu söylemek mümkündür.. Refik Halid'in Tan gazetesinde yazdığı ilk yazılar genellikle bu sürecin ilk dönemlerine aittir.

Refik Halid'in Ortadoğu ile ilgili yurda döndükten sonra ilkyazı serisi 7- 16 Haziran 1941 tarihleri arasında her gün yazılan yazılardır. Üst başlık olarak "Manda Altındaki Suriye 1, 2, 3 ve 4 isimlendirmesi ile yayınlanan yazıların alt başlıkları ve içerikleri 1918'den başlayarak Fransız Mandater yönetiminin Suriye'deki yönetimini odağa alır. Bu yazıların başlangıcında Refik Halid, Mütarekeden Şam İsyanına Kadar başlı̆ğ altında yazıların mahiyeti hakkında şu bilgileri verir:

"Milattan önceki devirlerden tutunuz da daha dünkü vukuata kadar bütün Suriye tarihini hem kitaplarda hem de yerinde uzun uzadıya tetkike zemin ve zaman bulmuş, bu memleketin yıllarca içinde yaşamış bir muharrir olmak itibarı ile niyetim notlarımı sıralamak ve bir eser hazırlamaktır." (Karay, 2017: 294)

Karay'ın açıklamasında belirttiği gibi onun yazılarının dikkate değer olmasının sebebi bu coğrafyada yaşaması dolayısıyla özellikle Suriye ve Lübnan'ın diline, kültürüne ve siyasî ortamına bilgi ve donanım olarak hâkim olmanın yazara sağladığı avantajı kullanabilmesidir. Suriye'nin 
Osmanlı idaresi sonrasında yaşadığı büyük problemlerin daha anlaşılır olabilmesi açısından Karay'ın yazılarının aydınlatıcı bir özelliği vardır:

"Hâlbuki Suriye bugün dünya efkârını üzerine toplamış, çok merak verici bir vaziyette bulunuyor. Diğer taraftan komşumuzun son 22 senelik karmakarışık ve yıpratıcı hadiselerle dolu sergüzeştini bilenler de pek azdır. 1919-1940 yılları arasında orası nelere şahit oldu, bilhassa Fransız manda idaresi ne şekilde işledi, bunların hülasasını yapmak faydalı olsa gerektir. Şu noktayı ilave lüzumludur: bu hülasa tamamen vesikalara istinaden vücuda getirilmiştir." (Karay,2017: 294,)

Manda Altındaki Suriye yazılarının ilki yukarıdaki açıklamayı da içeren Mütarekeden Şam Ísyanına Kadar, üst başlığının altında; Fransız Mandasını Suriyeliler İstedi mi ?, Askerî İsgal İdaresi, Illk Suriye Devleti'nin Hudutlarl, Üç Ay Süren Bir Devlet ve Bir İstiklâl, Lübnan Büyütülüyor, Suriye Küçültüllüyor, Garaud Geri Alınıyor; Weygand Bir Işs Göremiyor ve Sarail Felakete Sebep Oluyor, adlı alt başlıklardan oluşur.

İlk alt başlık olan Fransız Mandasını Suriyeliler İstedi mi? kısmında Milletler Cemiyeti'nin 24 Temmuz 1922 tarihli kararılla Suriye'yi Fransa mandasına vermesi anlatılır. Yazıda Karay, dünya ve Fransız basının Suriye halkının bu durumu istediği algısını yarattığı belirtir. Buna karşın aslında hazırlanan bir raporda Suriyelilerin istiklalin temini şimdilik mümkün değilse Amerikan mandasını tercih ettikleri bilgisi verilir. İkinci başlık olan Askeri İsgal İdaresi'nde Müttefikler ordusunun 1918'de Şam'a gelişi ile başlayan, Fransızların Trablus, Beyrut, Sûr ve Seyda bölgelerini ele geçirişleri ve İngilizlerin Şam, Hama, Homs ve Halep kentlerini Emir Faysal'a bırakışları ifade edilir.

1919'da İngilizlerin, Filistin ve Irak'a dönüşleri sonrasında Fransızların Suriye'nin idaresini büyük oranda ele aldıkları tespiti yapılır. 1916'da Suriyeliler iki devlet tarafindan kendilerine vaat edilen istiklallerini 11 Mart 1920'de Emir Faysal'1 kral seçerek ve 8 Mart 1920'de meclis kararı ile elde ettiklerini düşündükleri anlatılır. Bu Suriye'nin sınırları Halep, Hama, Homs, Baalbek, Buka, Hasbayya, Reşayya gibi mutasarrıflık ve kentlerden oluşuyordu. Fakat ülkenin denize çıkışı yoktu. $\mathrm{Bu}$ şartlarda bir devlet olmaya çalışan Suriye'nin istiklalinin çok sürmeyeceği algısı bu yazılarda Karay'ın şahsi değerlendirmesi olarak ortaya çıkar.

$\ddot{U}$ Ç Ay Süren Bir Devlet ve Bir İstiklâl başlığı altında Fransız General Gouraud'un Türkiye'ye karşı Kilikya harekâtında cepheye asker ve cephane sevki için Rayak-Halep demiryolunu cebren kullanmasının siyasi sonuçları anlatılır. Gouraud'un bir müstemleke valisi tavrıyla Kral Faysal'a ağır bir mektup yazması sonucu gelişen olaylar Karay'a göre Suriye'ye temin edilen bağımsızlığın gerçekçi olmadığının ilk göstergesidir. Zira bu olayda bir generalin doğrudan bir hükumetten talepte bulunuşu karşısında Kral Faysal'ın "yeni kazanılmış hürriyetin gururu tesiri ile hiddete kapılması" (Karay, 2017: 297) Batı'nın Suriyelileri istiklal vaadi ile kandırdığg gerçeğinin kısa sürede açığa çıkacağı olayları tetikler. Gouraud, 9 Haziran 1920'de Emir Faysal'a bir kesin uyarı verir art arda gelişen olaylarla Suriye hiçbir hukukî dayanağı olmadan Fransızlarca işgal edilir. Temmuz 1920'de Gouraud'un Şam'a girişi ile Batı'nın Suriye'ye verdiği istiklal vaadinin gerçekliği sadece 3 ay sürer. Bu işgale direniş gösteren Harbiye Nazırı Yusuf El-Azma ${ }^{3}$ nın mezarındaki rikkati tasvir eden Karay, bu tavrı ile gazeteciğin getirdiği gözlemci kimliği ile kalemindeki ustalığı fikra yazı türünde birleştirerek özgünlüğünü de gösterir. Karay, siyasî olayları anlatırken yerler ve isimler konusundaki titizliği ile dönemi açığa çıkarırken Türkçe'nin incelikli kullanımlarını da yazısına taşımayı başarır. Özgür olma hayaliyle Osmanlıya karşı tavır alan Arap devletlerinin umutlarının pişmanlığa dönüşmesi, paralelinde Karay'ın da fikirlerindeki değişikliklerin de takip edilmesine olanak tanır. Başlangıçta Avrupa'nın demokrasi ve özgürlükler

\footnotetext{
${ }^{3}$ Emir Faysal'ın savunma bakanı olan Azma bir Osmanlı subayıdır. Bazı belgelerde Yusuf El-Azma'nın Kilis'in Keferagni köyünde Millî Mücadele içerisinde savaşan Polat Bey'le Fransızlara karşı gizli mutabakata vardığı ifade edilir. (Bkz. Akşin, Sina (1986) Turkish-Syrian Relations in the Time of Faisal (1918-20), Turkish Yearbook of International Relations, Ankara, s. 3-17. Yılmaz, Hadiye, Mustafa Kemal Paşa-Emir Faysal Anlaşması ve Milli Mücadele Döneminde Suriye ve Irak, CTAD, Y1l 10, Say1 20, (Güz, 2014),s. 289-306. )
} 


\section{F.Ü. Sosyal Bilimler Dergisi 2018-28/2}

konusunda bir cihan ideali yarattı̆ğna inanan Karay, gözlemleri sonucunda bu hayalin ardındaki sömürü düzenini kavrar ve yazılarına taşır.

Karay'ın romanlarında ve gazete yazılarında özel bir ilgi ve sevgi ile bahsettiği Lübnan'1 Suriye' deki siyasî yazılarında daha çok orada yaşayan Hıristiyan azınlık üzerinden konu eder. Bu minvalde işgal yönetiminin ilk olarak Lübnan'daki bu azınlık üzerinden Lübnan'ın topraklarını arttırıp Suriye'yi baskılamak fikrinin Fransız manda yönetiminin temel stratejilerinden biri olduğunu iddia eder. Suriye'ye gönderilen Fransız Ho-komiserlerin Lübnan Hıristiyanları ile iyi anlaştığ 1 ve genellikle Müslüman çoğunluğun olduğu yerlerde dahi Hıristiyan yöneticileri atadıkları da Karay'ın gözlemleri arasındadır. Gouraud sonrası Suriye'ye gönderilen Weygand ve Sarail gibi generallerin de Suriye'de Fransızlara karşı artan nefreti önleyemediklerini belirten Karay'ın en dikkat çekici tespitlerinden biri de Marunî ve Hıristiyanların Manda idaresi ile olan ilişkileridir:

"Lübnan Hıristiyanları, bilhassa Marunîler teşkilatlarına güvendiklerinden dolayı şımarık idiler. Kiliselere gitmek ve sonu gelmez ayinlerde bulunmak firsatını kaçırmayan Weygand bile onlardan yaka silker, "Tahakkümlerinden biktım !" derdi." (Karay, 2017:299)

General Sarail'in Cebelidüruz ahalisini de gücendirmesinin yol açacağı Dürzî isyanını anlatırken Karay, mandanın din fark etmeksizin bir bölgenin yerli halkını memnun edebilecek bir yönetim şekli olamayacağını ifade eder. Suriye'de yaşayan Hıristiyan ve Dürzîlerin rahatsızlıkları üzerinden Batı'nın hürriyet, demokrasi ve eşitlik vaadi ile oluşturmaya çalıştığı kurgunun kendi emperyalist emellerine kolayca dönüşebildiğini vurgular. Karay'ın bu deneyimlerinin edebî yazılarındaki yansımalanı Gurbet Hikâyeleri, Yezidin Kızı ve Sürgün romanlarında gözlemlenebilir.

Manda Altındaki Suriye 1 yazısının en dikkat çekici yönü 1916'da Suriye'ye vaat edilen bağımsız yönetimin Avrupa'da ve Milletler Cemiyeti'nce idealize edilen şekli ile uygulanmayıp Ortadoğu'da emperyalist bir karaktere dönüşümünün ifade edilişidir. Zira Refik Halid'in sürgünlerinden önce Avrupa'nın siyasi ve etik değerlerinin belirli bir seviyeye kadar gerçekçiliğine inanan bir söylemi vardır. Bu açıdan bakıldığında Karay'ın tüm yazılarında geliştirdiği gerçekçilikle beslenen fikri altyapısının bir yanılgının tamiri olarak düşünülmesi de mümkündür.

Karay'ın yazılarda kullandığı üslubun hissettirdiği, genel olarak Avrupa ülkelerinin uygulayacaklarını söyledikleri, özgürlük ve halkların kendileri tarafından yönetilme vaadinin gerçekte bir karşılığı olmadığıdır. Suriye'deki siyasi gelişmelerin Avrupa ruhunu ve medeniyeti temsil etmekten ziyade özellikle İngilizlerin kendi çıkarlarını uzun süre koruyacak yerel bir yönetici ataması yaptığı ve emperyalizmin çok acımasızca uygulandığı bir alana dönüştüğü vurgusu ayrıntıların arkasındaki ana temadır. Yazılar bu coğrafyadaki halklara vaat edilen bağımsız devlet sözünün sadece 3 ay süren bir hülya olduğu ve emperyalizmin bağımsızlık vaadiyle Suriye topraklarına nasıl yerleştiği fikri etrafında ayrıntılandırılır.

Sykes-Picot'ta Suriyelilere sunulan vaatte, kısa dönemli bir mandater yönetimin sadece bağımsızlığa geçişte kullanılacağı ifade edilir. Fakat Karay'ın gözlemlerine göre olaylar, bu çerçevede gelişmemiştir. Karay'ın yazının tamamında geliştirdiği ana fikir, Avrupalıların demokratik söylemleri ile Ortadoğu politikaları arasındaki tezattır. Yazılarda 1919'da Suriye'nin Fransız mandası altına alınmasında yerli halkın herhangi bir etkisi olmadığı ve daha çok Amerika'nın bu kararda etkili olduğundan bahsedilmektedir. 1918'de başlayan süreçte İngilizlerin işgal ettikleri Suriye topraklarının büyük bir kısmı olan Şam, Hama, Homs (Humus) ve Halep'i öncelikle Emir Faysal idaresine bırakmaları da yazara göre sömürü planının kısa vadeli bir kandırmacasıdır. Olarak .

İngilizlerin 1919'da Suriye'yi terk edip alanı Fransızlara birakması, Fransızların bu coğrafyadaki etkisini arttırmasına sebep olur. Refik Halid'in yazdıklarına göre Fransız General Goraud'un 1920'debaşlayan Suriye işgalinin bu toprakların sömürgeleşmesinin ilk adımı olduğunu gözlemlemek mümkündür. Refik Halid, bu süreçte Hıristiyan azınlığın hakları öncelikli tutulmak suretiyle Lübnan'ın Suriye karşısında büyütüldüğünü ve Suriye'nin ciddî baskı altında kaldığını vurgular. Yazılarda 1920'den 1940'lara kadar Suriye'de tahakküm kuran Fransız generallerin sık 
sık değişmesinin huzur ve sükûna engel olduğu belirtilir. Bu karmaşadan daha çok Hiristiyan, Dürzî ve Marunî cemaatlerinin kazançlı çıktığı da Karay'ın odaklandığı ve önemsediği konular olarak göze çarpar.

Karay'ın Manda Altındaki Suriye 2 yazılarında, müstebit müstemleke generali Sarail'in fevri tavırlarının neden olduğu Cebelidürûz ayaklanması üzerinde durulur. Sarail'in müstebit tavrı karşısında Soltan El Atraş'ın önderliğinde başlayan ayaklanmanın ortaya çıkış sebepleri de Karay'ın kuvvetli gözlemleri ile ortaya konulur. Karay bu ayaklanmayı anlatırken zaman zaman bir romanc1 üslubunu da yakalar:

"Michaud kabiliyetsiz, silik, tembel bir zabitti. Bütün zamanını masasının başına geçip kumanda ettiği askeri kuvvetin bir kibrite, bir deste muma kadar hesaplarını tetkikle boşu boşuna geçirirdi... Sueyda Kalesi'nin granit taştan siyah ve heybetli şekli de ufukta belirdi. Michaud "Muvaffakiyet!" diye bağırmak arzusunu güç yeniyordu. Zabit yanına koştu, "Felaket!" diye haykırdı" (Karay, 2017: 302)

Ayaklanma Dürzî kuvvetlerinin galibiyeti ile sonuçlanır ve Fransızlar'ın Sueyda kasabasından çekilmesine yol açar. Bu arada Dürzî kuvvetleri Şam'ın güneyinden şehre girmeye dahi cesaret etmiş̧lerdir. Yerli halktan da destek alan Dürziler Ho-komiserlerin ikamet ettiği Azım Sarayı'nı kuşatıp Senegalli askerlerle çatışmaya girmiş ve sarayın bir kısmını tahrip etmiştir. Sarail bu durumda çatışmayı göze almamış ve kimseye haber vermeden Şam'ın bombardıman edilmesini emretmiştir. Birinciteşrin'in (Ekim ayının) 19. ve 20. günü 1925'te Şam'ın Fransızlar tarafından toplarla bombardımana tabi tutulmasını Karay, müstemleke yönetimlerinin hukuk tanımazlığının göstergesi olarak algılar. 1926 yılına kadar devam eden isyanın bu tarihten itibaren zayıflamasına rağmen, fikri olarak Fransız varlığından duyulan rahatsızlık devam etmektedir. Bu isyanın uzun vadede Fransızlar lehine dönüşmesinde büyük etkisi olan kolonel Collet'i de anan Karay, müstemleke yönetimlerinin ve kapitalist yapılanmanın Fransızları Suriye'de tutan önemli unsurlar olduğunu sık sık ima eder.

Karay bu yazılarda objektif bir tutum takındığını vurgulamak için kendi gözlemlerinin yanı sıra "hür fikirli Fransız muharrirleri" olarak tanımladığı Fransız yazarların kitaplarına da atıfta bulunur. Alice Poulleau'nun A Damas, sous les bombes (Şam'da Bombalar Altında) ve ismi anılmayan bir yazarın La verite la Syrie (Suriye Gerçeği) adlı kitaplarını anan Karay'ın bu tavrı özgür ve muhalif düşüncenin de hâlâ Avrupa aydınlarında bulunabileceğine inancını da gösterir.

Manda Altındaki Suriye 3 üst başlıklı yazılar Fransızların Suriye’ye atadıkları yöneticiler olan Ho-Komiser'in hukuksuz ve sorumsuz tavırlarıyla Suriye'de yarattıkları felaketleri işler. Hokomiserler Resmî Geçidi üst başlığı altında General Gouraud'un İdare Tarzı, Kurulan Bir Uzak Şark Müstemlekesidir, General Weygand'ın Yaptıkları, De Jouvenal Işs Başında; Bir Tefeci Paşa Oluyor Oğulları Prens, Beşinci Ho-Komiser Geliyor, Ho-komiserler Nasıl Seçilir ?, Ponsot ve De Martel başlıklı yazılar bulunur.

Refik Halid Karay, ilk yazı olan General Gouraud'un İdare Tarzı'nda, General Gouraud'un Hıristiyanlığa aşırı bağlılı̆̆ı, arazi ele geçirme hırsı ve tüm sorunları kaba kuvvetle çözebileceğine inanması dolayısıyla müstemlekeci bir ruh yapısına sahip olduğunu ve bu sebeple bazı hatalar işlediğini vurgular. Bu hatalar sadece Gouraud'un değil tüm Fransız yöneticilerin hataları olarak değerlendirilir. Karay’ın tespitlerine göre bu hatalar:

1- Müstakil Suriye devleti topraklarına göz dikip verilen söz hilafına, sırf İngiltere'yle rekabet için bir vesileyle oraları ele geçirmesi

2- Kilikya adı verilen öz Türk topraklarını işgal etmeye çalışması

3- Müslüman Suriye'nin küçültülüp Hıristiyan azınlıkların Lübnan lehine büyütülmesi,

4- Önemli bir liman olan Trablus'un Suriye'den alınmas1

5- Fransa'nın Milletler Cemiyeti'nin Paktının idare kararlarını (22. Madde) hiçe sayarak yerli hükümetleri kukla mertebesinde görmesi

6- Ho-Komiserlik dairelerini binlerce Fransız memuru ile doldurmas1 


\section{F.Ü. Sosyal Bilimler Dergisi 2018-28/2}

7- Kilikya'dan boşaltılan Hıristiyanları Lübnan'a yerleştirip bunlara asıl ahaliden fazla imtiyaz vererek onları kullanmasıdır.

Tüm bu tercihlerin Suriye'yi bir uzak şark müstemlekesi haline getirdiği bu yazılarda vurgulanır. Bu yazıların arka planında zaman zaman Osmanlı'nın tasfiyesinden sonra içlerinde kendisinin de bulunduğu bazı Türk aydınlarının aklına gelen manda yönetiminin sürdürülebilir bir model olmadığının emareleri gizlidir.

Karay, Fransızların Ortadoğu politikalarındaki sorunun sadece oraya atanan yöneticilerin beceriksizliği ile ilgili bir durum olmadığını vurgulamak için Weygand, De Jouvenel, Ponsot, De Martel gibi Ho-komiserlerin (yüksek komiser) yönetici olarak görev yaptıkları dönemleri de ayrıntıları ile anlatır. Bu tavırla Karay, Ortadoğu'da bu dönemde yaşanan kargaşanın bireysel tercihlerle değil Batı medeniyetinin bu konudaki açgözlü politikalarına uygun olarak oluşturulmuş sömürücü yapılarla ilgili olduğunu vurgular. Weygand'ın Suriye'yi 6'ya bölmesi, Cebelidüruz'a idarî muhtariyet verilmesi, yerlilere verilen haklarda işbirliği şartının gözetilmesi gibi birçok konu bu politikaların esas niyetini açığa çıkarmak üzere kullanılmış örneklerdir.

Manda Altındaki Suriye 3 yazısının bir alt başlığı olan Bir Tefeci Paşa Oluyor, Oğulları Prens kısmında Fransız mandası altındaki Suriye'de birden zenginleşen ve yönetici konumuna geçen kişilerin durumu üzerinde durulur. Suriye-Filistin Cemiyeti'nin başında bulunan ve Arap istiklalini isteyen Prens Lütfullah'ın aslen Ortodoks bir Hıristiyan olan Habip Paşa'nın oğlu olduğu ve tefecilikle elde edilmiş büyük bir servetin varisi olduğu bilgisi, yerel işbirlikçilerin Suriye'deki niteliklerini açıklamak açısından önemlidir. Fransızların Komiser De Jouvenal döneminde Fransız muvakkat hükumetini değiştirip Sultan Abdülhamit'in sabık damatlarından Ahmet Nami Bey'i devlet reisi olarak ataması, Osmanlı nüfuzundan yararlanarak Fransızların bu çevrede sükûn temin etme gayreti olarak yorumlanır. Fakat bu gayretin amacına ulaşmadığı da ifade edilir. Tüm bu girişimlerin olumsuz sonuçlanmasını Karay, Fransızların Suriye'ye gönderdikleri yöneticilerin hiçbirinin bu coğrafyayı tanımıyor oluşlarına bağlar. İç politikada kuvvetli çatışmalarla uğraşan Fransız hükumetinin istikrarsız ve emperyalist politikalarının da bu çeşit yöneticilerin Suriye'ye gönderilmesindeki kronik yanlış olduğunu ileri sürer.

1922 'den itibaren Fransızların Suriye'de yaşadıkları problemleri denize ulaşımdan mahrum bıraktıkları Suriye'yi bölgelere bölerek çözmeye çalışmaları üzerinden istikrarsızlık vurgusu yapılır. Bu yorumlarda Refik Halid, V. De Saint Point, Pierre la Mazierre gibi Fransız oldukları anlaşılan yazarlardan yaptığı alıntılarla üslubunu evrensel ahlakî kurallarla uzlaşan bir çizgide kullanarak objektifliğini de vurgular:

"Yalnız 1920-25 arası 5 yıllık kısacık müddette gerek arazi gerek idare şekli bakımından Suriye'nin kaç türlü değişikliğe uğradığına dikkat edilince Fransa'nın kararsızlığı, programsızlığı hatta şaşkınlığ tamamıyla meydana çıkar.” (Karay, 2017: 308)

Bu parçalı yapının Suriye, Lübnan, Aleviyyin, Cebelidürûz, İskenderun Sancağı gibi farklı bölgelerde tam bir karmaşanın devamına sebep olduğu ve istikrarsızlığın bu surette sürekli kılındığı yazılardan anlaşılan bir başka durumdur. Bu durum kukla yerli idarelerin çok basit işleri dahi yaptıracak otoriteye sahip olamadığının göstergesidir. Karay’a göre manda idaresinin Suriye bütçesinden her sene aldığı 95 milyon Frank, yine Suriye halkına ödetilmektedir. Bu açıdan bakıldığında istikrarsızlığın nedeni daha açık anlaşılabilir.

"Milletler Cemiyeti Suriye ve Lübnan mandasını Fransa'ya bir şartla vermişti. Bu şarta göre manda yönetimi devreye girdikten en fazla üç yıl sonra yerli hükumetlerle bağ kurularak anayasa yapma imkânı sunulacak ve halkın arzularını dikkate alan bir yönetim tesis edilecekti. 1922'de devreye giren mandater yap1 1930'da kabul edilen Suriye anayasasını dahi tam anlamıla tatbik edememişti." (Karay, 2017: 312)

1926'dan itibaren Fransa'nın yerli nasyonalist Araplarla çeşitli vesilelerle uzlaşma yoluna gittiği ve fakat 1932'de Mebusan Meclisi'nin toplanmasına kadar kargaşanın sürdüğü bu yazılarda 
tafsilatıyla anlatılır. Arap İzzet Paşa'nın oğlu Mehmet Ali El Abid, Başvekil Şeyh Tacettin gibi yöneticilerin de Mebusan Meclisi'nin de kargaşaya mani olacak politikalar geliştirememesi Fransız müstemlekesinin devamlılığının başka bir sebebi olarak yazılarda vurgulanır.

Manda altındaki Suriye'nin idari yapısına eğilen Manda Altındaki Suriye 4 yazıları manda yönetimine atanan, sorumsuz ve acımasız yöneticilerin Suriye'nin yapısında vücuda getirdikleri tahribatı içerir. "Osmanlı zamanında 1914'te sadece 350 memurla idare edilen Suriye'nin Fransız mandasında 4000 memurla idare edilemediği ve bu memurların masraflarının tamamının Suriye halkına ödetildiği (Karay, 2017: 317) düşünüldüğünde idari yapı hakkında bir fikir edinilebilir. Bu çerçevede Hükümsüz Hükumetler Serisi alt başlığında manda idaresinin kuklalaştırdığı yerel idareleri, Emir Kulu Yerli Memurlar başlığında, manda idaresi ile birlikte çalışan yerlilerin daha çok işbirlikçi ve vasıfsız insanlardan oluştuğu anlatılmaktadır.

T.O.E. Ne Demektir ? başlığı altında mandanın Suriye ve Lübnan'da oluşturduğu istihbarat şebekesinin mahiyeti TOE (Theatre des operations exterieurs) kavramı üzerinden anlatılır. Fransız ordusunda disiplin sorunları çıkartan ve ordudan atılması gereken subay ve askerlerin (ve onların eşleri konumunda oldukları söylenen kadınların) Suriye'ye gönderilmesinin Suriye'deki huzursuzluğun nedenlerinden biri olduğu ifade edilir:

“... emirleri altındaki silahlı kuvvetleri suiistimal vasıtası yapmışlardır. Kendilerine birer derebeyi payesi vermişler; senyör, şövalye tavrı takınmışlardır.” ( Karay, 2017: 321)

Tüm bu yapının sonucu olarak 1920'de Havran Kıyamı, aynı sene Alevî ve Bedevîlerin isyanı, 1921 'de Hama, Homs ve Deyrizor vukuatları, büyük Dürzi isyanı gibi olaylarla 22 yıllık manda yönetiminde asla sükûnetin ve huzurun oluşmaması bir yana Fransızların masrafları ve kayıpları ile Suriye'den zararlı bir biçimde ayrıldıkları ifade edilir. Tüm bu zararı da yerli halka ödeten Fransa örneği üzerinden I. Dünya Savaşı sonrası ülkelere medeniyet götürme vaadi ile oluşturulan mandater yönetimlerin esas emperyalist amaçları bu yazıların omurgasını oluşturur.

$\mathrm{Bu}$ dönem yazılan yazılarda ana odak Suriye ve Lübnan'daki emperyalist etkiler olmakla birlikte daha çok bu ülkelerin özgün yapıları ile ilgili tespitlere rastlanır. Örneğin 11 Haziran 1941 'de Tan gazetesinde müstakil olarak çıkan İçinden Çıkılamayan Mesele yazısı Ortadoğu'daki dinî ve mezhebî çeşitliliği isimler üzerinden okuma girişimi olarak ifade edilebilecek bir metindir. Ortadoğu'da Rum, Ermeni Arap, Protestan, Katolik, Marunî, Nasturi, Süryani, Melkit gibi birçok yapının yaşadığı ve bunların -Abdullah- gibi isimleri ortak kullanmasının yarattığı karmaşanın siyasî yapıdaki karmaşa ile organik bir bağı olduğu oldukça ironik bir dille izah edilir:

"Şair Şeyh Nimetullah Mübarek, bir doktor El Hac Ebu Selame, bir mühendis Emir Kazım Şemseddin ile tanışırsınız. Hay nurlu ve mübarek isimli Müslümanlar hay! Sakın aldanmayınız! Birincisi koyu Marunî, ikincisi mutaassıp Rum-Ortodoks, üçüncüsü zünnarlı Katolik’tir... Suriye'de kadına ve boğaya tapanlar gibi gizli ve acayip itikattakiler bir yana dursun resmen tanınmış 30 adet din ve mezhep mevcuttur. Ben on yedi sene işin içinden çıkamadım; affa uğrayıp kurtuldum. Fransizlar da yirmi sene bocaladilar ve bu defa istiklal vermek suretiyle kendi kendilerini affedip zannederim kurtulmanın yolunu buldular." (Karay, 2017: 326)

16 Haziran 1941'de Refik Halid'in Tan gazetesinde yazdığ son yazı Yanlış Anlaşıllmasın Diye başlıklığını taşır. $\mathrm{Bu}$ yazıda Karay, ellerinde beyaz bayraklarla müstemleke ordusuna katılan Fransızlara ateş açanların yarattığı karmaşayı anlatır. Ona göre bu olayı; vatanseverlik, millî iman ile ilgisi bulunmayan kişiler gerçekleştirmiştir.. Yazıda genel olarak Suriye'nin gerçek yerlileri ile müstemleke yanlıları (Karay bunların daha çok göçmen, çapulculardan oluştuğunu belirtir.) arasındaki farklara dikkat çekilir.

\section{Ortadoğu'ya Dair Tespitler İçeren Yazılar}

Refik Halid'in 1941 'den sonra Ortadoğu ile ilgili yazılara bir süre ara verdiği ve Ağustos 1943 'te Tan gazetesinde yine aynı konuya döndüğü görülür. 1943'ten sonraki yazıların alt başlıklar içermeyen daha kısa ve spesifik yazılar olduğu söylenebilir. Bu yazılardan özellikle 1946 sonrası 


\section{F.ய̈. Sosyal Bilimler Dergisi 2018-28/2}

gelişmelerle ilgili olarak Karay'ın ilk yazılarında görülen Ortadoğu sempatisinin, Arap Milliyetçiliği, Türkiye Ortadoğu ilişkilerindeki gerilimler nedeniyle kaybolduğu söylenebilir.

12 Ağustos 1943 tarihinde Tan gazetesinde yayınlanan Bir Damla İksir yazısında Cezayir'de Araplara verilen yeni hakları ironik bir biçimde ifade eder. Bu yazıda Fransız İhtilali'nin getirdiği hak, adalet, eşitlik gibi kavramların Batı lehine tek yönde işletildiği eleştirisi güçlü bir biçimde hissedilir. Kendi memleketlerinde basit bir memur olabilmek için Fransızların hak tanımasını bekleyen Cezayirlilerin durumunun modern dünyadaki eşitlik, adalet ve özgürlük kavramlarının hiçbiri ile izah edilemeyeceği vurgulanır:

"Bütün bunlardan anladığımıza -eskiden de bildiğimize- göre demek ki Cezayir Araplarının Fransız istilasından beri yani bir asırdır, öz memleketlerinde belediye reisi muavini olmak dahi çok görülmüş̧; şirketlerin idare meclislerine dahi giremezler, kendi sermayeleriyle dönen müesseselerde olan biten meseleler hakkında tek söz söyleyemezlermiş. İşte büyük ihtilalden başlayarak son günlere kadar dünyaya hürriyet, adalet, müsavat dersi veren Fransa'nın Frikiye takkesi altında sakladığı o güzel baş bu çürük beyni taşır.” (Karay, 2017: 329)

14 Kasım ve 17 Kasım 1943 tarihli Tan gazetesi yazıları Cihan İdealine İndirilen Şamar ve Lübnan Üzerine Hakikatler başlıklarını taşır. Bu tarihlerde Lübnan Cumhur reisinin ve hükumet azalarının Fransız Kurtuluş Komitesi emri ile Senegalli askerlerce tutuklanması ve 1. Dünya Savaşı'nda gönüllü olarak Fransızlardan yana olan fakat şimdi onlarla savaşan Lübnanlılar üzerinden mütalaalarda bulunulur. Genel bakış açısı Fransızların baskıcı ve plansız müstemlekeci tavırlarının coğrafyaya ve Fransa'ya huzur getirmeyeceği ve dünya idealine zarar vereceği yönündedir.

Karay'ın Tan gazetesinde 1944'te Ortadoğu ile ilgili son yazısı Lavrans Nerdesin, Kulakların Çınlamıyor mu? yazısıdır. Bu yazı Arap kavramının mahiyeti üzerinedir. Dışarıdan Arap çatısı altında tanımlanan Ortadoğu'nun lisan birliği ve ırk birliği taşımadığı; bu birlikleri taşıyan unsurların da daha büyük ayrıllk vesileleri ile birbirlerine karşı diş biledikleri ifade edilir. Amerika'nın önerdiği federasyon düşüncesini bu şartlarda imkânsız bulan Karay, bu ayrıllı̆̆ şöyle ifade eder:

"Mısırlıyı Arap sayamayız... Mısır iktisat bakımından hâlâ Firavunlar ülkesidir. İmtiyazlı sınıfın manevi kırbacı altından iki büklümdür. Arap federasyonunun başına da görünüşe göre bu sınıf geçecektir... Suriyeli ise bazı politikacıların gayretine rağmen hala Arap ırkından geldiğini ispat edememiştir... Birbirine zit yüz çeşit ırk, din, mezhep ve menfaat bölgesidir... Hıristiyan Lübnanlıya "Sen Arapsın !” demeye hiç gelmez, küplere biner. Dürzü ise yalnız Dürzü'dür. Alevi için sadece Alevilik vardır. Irak, Iraklıdır. Bu memleketin Türk ve Kürt olan şimal kısmı ile cenubu arasında lisan birliği de yoktur... Beriberi Arapçasını Arap anlamaz" (Karay, 2017: 341-343).

Tüm bu açiklamalardan sonra Arap federasyonu hamlesinin Fransa'nın boşluğunu Akdeniz'de doldurmak isteyen Amerika'nın bir girişimi olarak yorumlayan Karay, bu politikanın Lavrans'ın yarattığı karmaşadan daha büyügünü yaşatacağı öngörüsünde bulunur. 1952'de Misır'daki General Necip darbesinden sonra Cemal Abdülnasır'ın kuvvetle uyguladığı politika olan Arap milliyetçiliği, Suriye'nin Misır'la birleşmesini öngörmektedir. Ortadoğu'daki nasyonalist politikaların Amerika'nın bölge üzerindeki emelleriyle ilgili olduğu bu yazılardan hareketle hissedilmektedir.

1945'ten 1947'ye kadar Akşam gazetesinde Ortadoğu ile ilgili olarak Karay'ın sadece 4 yazıs1 vardır. İlk yazı olan Topa Tutulan Parlamento Binası 1945'te bombalanan Şam ve bu bombardımanda yıkılan parlamento binası ile ilgilidir. 1925 'te ve 1945 'te iki kez gerçekleşen bombardıman hadiselerini Karay, Fransa için utanç duyulacak bir olay olarak algılar. Karay bu biçimde Batı'daki demokrasinin kurucusu kabul edilen Fransa'nın kendi prestijini Suriye'de kaybettiğini ifade eder. İkinci Yazı olan Made in Madagaskar 2 Kasım 1945 tarihlidir. Yazıda Yahudilerin Madagaskar adasına yerleştirilme planları hakkında ironik tespitler vardır. $\mathrm{Bu}$ tespitlere göre bu durum gerçekleşirse Madagaskar adasının gelecekte dünyanın en gelişmiş 
yerlerinden biri olacağ eleştirilir. Türk-Lübnan Dostluğu adlı yazı, Lübnan'ın istiklali üzerine yazılmıştır. 4 Nisan 1955'te Akşam'da yayınlanan Lübnan Devleti ve 6 Aralık 1956'da Yeni İstanbul gazetesinde yayınlanan Lübnan'ın Kıymeti yazıları da bu yazıyla benzer olumlu yönelimler içerir. Karay'ın Lübnan ile ilgili dikkatlerinde, olumlu geçen Lübnan yıllarının etkisi hissedilir:

"Bu memleket ahalisi hem çalışkan, hem terbiyeli, hem de şen ve sevimlidir. Yaradılıştan medenîdir; ayrıca Türk dostudur. Yıllarca gezip tozduğum komşu ülkeler arasında bir an olsun incinmediğim yer, Lübnan'dır. Lübnan'ın her ırka, her dine, her ictimai seviyeye mensup cemaati Müslüman eşraf, Marunî papazları, Dürzî şeyhleri, Rum Ortodoks ve Katolik tabakası, eskiden yerleşmiş Katolik Ermeniler- hepsi Türk'e karşı sevgi ile karışık saygı besler.” (Karay, 2017: 352)

Akşam gazetesinde 17 Ocak 1947 tarihli “Bayır- Bucak'a Dair” yazısı bugün de üzerinde çokça konuşulan Bayır-Bucak Türkmenleri üzerinedir. Karay, bu bölgede Türk'ten başka "ferdi aferide" rastlanmadığını belirtir ve bu bölgenin yapısı dolayısıyla özgün dil ve kültürel özelliklerini muhafaza eden Türkmenlerle ilgili detaylı bilgi verir. Bu dönemde Suriye hükumetinin BayırBucak Türkmenlerine yaptığı eziyetler dolayısıyla bu konuya eğilen Karay, bu konuda çarpıcı üslubuyla bugünü de aydınlatacak saptamalarda bulunur:

"Bu derece lisanına, âdetlerine, anane ve ırk icaplarına bağlı, sadık, vefalı kalmış bir Türk cemaatine değme yerde rastlanmaz... Öz Türk lügatı, bu halkın lügatı tetkik olunmadıkça tamamlanamaz; folklor bakımından da büyük istifadeler temini mümkündür." (Karay, 2017: 354355)

1949'dan itibaren Karay'ın yazılarında İsrail, Mısır ve Suriye'de gelişen olayların ağırlık kazandığı görülür. 19 Şubat 1949'da Ay Dede'nin 83. sayısında çıkan Bize mi Düştü başlıklı yazıda Karay, yeni kurulan ve hızla gelişen İsrail devleti ile ilişkilerimizde ticari ve seküler menfaatleri gözetmemiz gerektiğini vurgular. Bu yumuşak tavırlı yazının hemen ardından 26 Şubat'ta Aydede'de yayınlanan Haydi Güle Güle yazısında Türkiye'de yaşayan Yahudilerin Filistin'e göç edişleri eleştirel bir gözle değerlendirilir. Yazıda "varlık vergisi" konusunda Yahudilerin Türkiye'ye karşı geliştirdikleri olumsuz tutum eleştirilir.

Karay'ın 1949 sonrası yazılarında Ortadoğu'daki siyasî ve sosyal değişimlerin izini sürdüğü görülür. Karay'ın bu dönemde yazdı̆̆g yazılarda sadece Suriye ile ilgilenmediğini, Irak, Mısır ve Lübnan'daki siyasî gelişmeleri dikkatle gözlemlediğini belirtmek gerekir. Zira Karay’a göre özellikle Arap milliyetçiliğinin yükselişi ve bölgedeki Amerikan etkisi, Ortadoğu ülkelerinin Türkiye ile ilişkilerinde de birinci derecede belirleyici etken olmuştur. Bu gelişmeler karşısında Refik Halid, gözlemlediği dönemdeki Ortadoğu ile 1949'dan başlayan değişimi karşılaştırırken evrensel şartlar ile Ortadoğu'nun özgün yapısı arasındaki gerilimi içeriden biri gibi değerlendirir.

1949'dan 1954'e kadar Suriye'de dört defa hükümet darbesi, yirmi bir kabine değişikliği olmuş ve iki defa da askeri diktatörlük kurulmuştur (Armaoğlu, 2007: 506). İlk darbe, Albay Hüsnü Zaim tarafindan komünizm tehlikesine karşı ve 1948 Arap-İsrail Savaşı'nda alınan yenilgiye tepki olarak 30 Mart 1949 tarihinde gerçekleştirilmiştir. İkinci darbe ise Albay Hınnavi tarafından 15Ağustos 1949 tarihinde yapılmış ve Suriye Cumhurbaşkanı Zaim ve Başbakan Muhsin Barrazi kurşuna dizilmiştir. Hınnavi'nin tutuklanarak hapse atılmasıyla sonuçlanan üçüncü darbe girişimi ise Edip Çiçekli tarafından 19 Aralık 1949 tarihinde gerçekleştirilmiştir. Dürzilerin başlattı̆̆ ayaklanma ve siyasi partilerin verdiği destekle zayıflayan Edip Çiçekli iktidarı ise 25 Şubat 1954 tarihinde yaşanan dördüncü darbe ile devrilmiştir. Öte yandan Mısır lideri Nasır'ın, 1958'de Suriye ile Mısır arasında Birleşik Arap Cumhuriyeti'nin (BAC) kurulmasının ardından Suriye'de siyasi partileri yasaklayıp burayı Mısır'ın bir eyaleti gibi yönetmeye başlaması sonucunda bazı tepkiler ortaya çıkmaya başlamıştır. Nitekim kısa bir süre sonra da Suriye ordusu 28 Eylül 1961 tarihinde yaptığı darbeyle, Suriye'yi BAC'dan ayırmıştır. Böylece Suriye'deki darbeler sürecinin 1963 yılındaki Baas iktidarına kadar sürecek olan ikinci perdesi açılmıştır (Öztürkci, 2017: 378). 


\section{F.Ü. Sosyal Bilimler Dergisi 2018-28/2}

1957'de Suriye'nin Vaziyeti adlı yazıda tüm bu olayların Suriye'deki parçalı yapının daha keskin bir biçimde devam ettiğini belirtir Refik Halid Karay.

Karay'ın 20 Ağustos 1949'da Aydede'de yazdığı Kemirici Politika Nöbetleri yazısı Zaim darbesi üzerine yazılmıştır. Zaim'in üç aylık diktatörlüğünün cezasını çabuk bulmasını, cihan siyaseti namına bir kazanç olarak gören Karay, Suriye'de bu tür darbelerin devamlı olmaması için dua ederken âdeta gaipten haber verecek bir yorum yapar. Karay'in 10 Eylül 1952'de Akşam gazetesindeki Beylik, Paşalık yazısında Ortadoğu ülkelerinin yönetimde veya sosyal alanda yaptıkları Batı odaklı değişikliklerin gerçekte bir karşılığı olmadığı vurgulanır. Mısır ve Ürdün'de "Bey" ve "Paşa" unvanlarının resmi olarak kaldırılışının asıl nedeninin bu devletlerin modernleşme çabalarını değil; Osmanlı'ya ve Türklüğe karşı değişen tavırlarının göstergesi olduğunu vurgular. Yazıya ustalıkla yerleștirilmiş ironiden Karay'ın Türkiye'de bu unvanların kaldırılışının sosyal etkilerinden de rahatsız olduğunu anlamak mümkündür. 19 Ocak 1955'te Akşam'da Re-Ha imzasıyla yayınlanan $B u$ da Böylesi adlı yazı Suriye halkına eleştirel bir gözle bakılan bir yazıdır. Refik Halid'in 1952 sonrası Mısır-Suriye yakınlaşmasının ve Arap milliyetçiliğinin yükselmesinin ardından, Ortadoğu ülkelerine, özellikle Suriye'ye karşı daha önceki müsamahakâr tavrında ciddi değişiklikler gösterdiğini yazılardan hareketle gözlemlemek mümkündür. Karay, 19 Kasım 1956 'da Yeni İstanbul'da yazdığı Arapsaçı adlı yazıda Arap devletlerinin şımarıklığının Avrupa ve Amerika'nın Ortadoğu'ya müdahale etmemesinden kaynaklandığını ifade eder. Mısır'ın Ortadoğu'daki diğer ülkelerle Arap milliyetçiliği ekseninde kurmaya çalıştığı ortaklığ Müslümanlık üzerinden genişletmeye çalışırken Türkiye'yi eleştirmesini 24 Aralık 1956'da Yeni İstanbul'da yayınlanan Türrehat yazısıyla ele alan Karay, bu vesile ile Osmanlı Devleti'nin ve Türklerin İslamiyet'e hizmetlerinin sosyal sonuçlarını da açıklar:

“Türkler, Müslümanlığı kabul etmeseler ve o derece imanla hizmetine girmeselerdi acaba Misırlı, Suriyeli mi bu dini muhafaza edecekti? Neyi muhafaza etmişlerdir ki onu korumuş olsunlar. Eğer Türkler bir İslam İmparatorluğu kurmasaydılar şimdi Müslümanlık namına bizi tartaklayanlar çoktan Nasranileşmiş, memleketleri de çan kuleleri ile bezenmiş hale gelirdi. Biz yine Müslüman kalırdık ve bugün bize "Müslümansınız !" diye çatarlardı! Efendi değiştirmekten zevk alanlar din değiştirmekte de güçlük çekmezlerdi." (Karay, 2017: 382)

$\mathrm{Bu}$ derece sert bir söylemin başlangıçtan itibaren Ortadoğu'ya dair umutlar besleyen fakat her gelişmede hayal kırıklığı yaşayan bir aydının zihninin yansımaları olduğunu belirtmek gerekir. Bu umutsuzluk Refik Halid'in söyleminde Türkiye milliyetçiliği söyleminin yükselmeye başlamasının da nedenidir. Ortadoğu'da yükselen Arap milliyetçiliğine karşı Refik Halid'in yazılarının bu yolda geliştiği söylenebilir. 1957'de Ürdün hükumetinin Türkiye nezdindeki büyükelçiliğini lağvetme kararı Karay’ın ironik üslubuyla 5 Ocak 1957 tarihli Andığımız Heccav yazısında görülür.

8 Mart 1955'te Akşam'daki Beslediklerimiz ve 25 Ağustos 1956'da Yeni İstanbul'daki Et ve Ot yazıları Suriye Türkiye sınırındaki hayvan ve ticari mal kaçakçılığı üzerinedir. Bu yazılarda Suriye'nin Türkler tarafından vergisiz kazançlarla beslendiğini ifade edecek kadar sertleşen Karay'ın bu tavrı Suriye tarafının bu dönemde Türk tarafına gösterdiği sert tavırla doğru orantılıdır:

"Cenup komşumuz ahalisi nümayiş yapmayı pek sever. Diyebiliriz ki yılda birkaç defa sokaklara dökülüp bağırıp çağırmaz, cam çerçeve kırmazsa içi rahat etmez; o yılı âdeta boşa harcamış, zevksiz geçirmiş gibi üzüntü duyar... Meselâ bir parti veya şahsın aleyhine ayaklanır, az sonra aleyhine. Bugün Misır'1 destekler yarın kahrolsun avazeleriyle yine ona hücum eder... Tabiidir ki bu nümayişler ahvalin gidişi üzerine hiçbir tesir yapmaz. Yine Misır Müslüman Kardeşler'i asar, yine İsrail Almanya'dan tazminat alır ve yine Irak lüzumlu gördüğü ittifaka girer ve komünistlerle münasebetini keser." (Karay, 2017: 362)

Karay tüm bu eleştirileri Ortadoğu ülkelerinde bir devlet geleneğinin oluşmamasından kaynaklanan bir ciddiyetsizlikle açıklar. Bu ciddiyetsizlik, sadece Suriye ve Misır'a değil; tüm Arap ülkelerine yöneliktir. Örneğin 1 Aralık 1956'da Yeni İstanbul'da yayınlanan Üye Hazretleri yazısında Birleşmiş Milletler'deki Yemen delegesinin Kıbrıs'ın Yunanistan'a verilmesini isteyen 
konuşması karşısında Refik Halid'in tavrı oldukça ilginçtir. 25 Ocak 1955 ve 28 Şubat 1955 'te Akşam'daki Hamdolsun ve Hazır Ol Emri yazılarında Mısır'daki yönetimin fevri hareketlerinin devlet ciddiyetine yakışmadığını 15 Şubat'ta yine aynı gazetedeki Bir Kuvvet Kaynağ yazısında ise Suriye'deki bazı partilerin Türkiye'nin Suriye'nin iç işlerine katıldığı suçlamalarını dillendirmelerinin devlet ciddiyetine sığmadığını ifade eder. Bu tavrın bir başka nedeni Fransız işgali sonrası $1955^{\prime} \mathrm{e}$ kadar hiçbir parti veya hükumetin istikrarı kuramadığı bir ülke olan Suriye'nin Türkiye karşısında geliştirdiği politikaların Avrupa, Amerika veya Mısır baskısıyla oluşturulması dolayısıyladır. 18 Mart ve 1 Nisan 1955 'te Akşam'daki Ístikrar ve Destekleme yazıları bu imayı içerir.

16 Kasın 1956'da Yeni İstanbul'daki Efendi Değiştiren yazısında Karay'ın Suriye halkı hakkında yaptığı tespitlerin gittikçe sertleştiğine şahit olunur. Karay, efendi değiştirmenin Suriye'nin millî seciyesi olduğunu belirtirken Suriye'nin son olarak "kapılanmak istediğì" Rusya tehlikesini 1956 Macar devrimi ile örnekler. Nitekim 1955 sonrasında SSCB'nin Suriye üzerindeki nüfuzunun artışını Suriye Komünistliği yazısıyla ifade eden Karay, bu konuda liberalliğini muhafaza ederek komünizm karşıtı bir noktada kalır. Bu yazıda Suriye'de sol cereyanların Ermeniler üzerinden harekete geçiriliyor olmasının Karay'ca ifadesi oldukça dikkat çekicidir. Suriye yöneticilerinin Ermeni Taşnak ve Hınçaklar'la beraber hareket edip Lübnan'ın buna tenezzül etmemesini de vurgulayan Karay, bu desteğin zamanla Suriye'nin de başını ağrıtacağı öngörüsünde bulunur.

Mısır'da 1952'de Hür Subaylar adı verilen bir grup, Kralı Faruk'un İskenderiye'de bulunduğu sırada başkent Kahire'de bir hükümet darbesi yaparak kontrolü ele geçirmişlerdi. Kral Faruk'un gezme ve eğlenceye düşkünlüğ̈̈, bar ve kumarhanelerde büyük paralar harcaması ve 1948 Arapİsrail Savaşı'nda Mısır ordusunun mağlubiyeti fakir Mısır halkı ve ordu içerisinde "Kavalalılar" hanedanına karşı bir tepkinin doğmasına neden olmuştu. Yürütmenin yetkileri kısa sürede devrimin önderlerinden Cemal Abdülnasır'ın elinde toplanmış ve Mısır'da Enver Sedat ve Hüsnü Mübarek dönemi de dâhil olmak üzere Krallık gibi bir tek adam yönetimi oluşmuştu (Soran, 2005). Bu süreçler esnasında Karay'ın yazılarında Mısır'daki Abdülnasır hâkimiyeti, nasyonalist politikaların Suriye üzerindeki etkisi, Rusya'nın bu süreçte Suriye'de etkili olma çabaları yazıların içeriğini şekillendirmektedir. Mısır'la ilgili olarak darbe öncesi Kral Faruk yönetimi için de çok olumlu görüşler taşımayan Karay bu görüşlerini Hazır Ol Emri ve Kötülü̈̆e Himaye yazılarında belirtir:

“Mısır'ın başında çok acemice hareket eden bir ihtilal hükumeti var. Esasen bu devlet yaşlı başlı rical elinde bulunduğu zaman bile pek iyi idare olunamazdı. Suiistimal önlenemezdi, daima skandallere meydan verilirdi. İsrail ile savaş halindeyken silahların düşmana satıldığına şahit olmuştuk." (Karay 2017: 365)

Darbe sonrası hükumeti bu biçimde eleştiren Karay, 30 Nisan 1955 tarihli Akşam gazetesi yazısında tahttan indirilen Faruk'un dış odaklar tarafından desteklenmesini de kötü niyetli bulur. $\mathrm{Bu}$ dönemde Karay'ın Mısır ve Suriye hakkındaki yazılarında başlangıçtaki liberal veya Anglosakson muhafazakârlığına benzetilebilecek tavırlarından tamamen uzakta ve oldukça sert bir yönelim içinde olduğu söylenebilir. Karay, 3 Aralık 1956'da Yeni İstanbul'daki Firavunlar başlıklı yazısında, Nasır, Hitler ve Mussolini gibi silaha sarılarak diktatörlükle yönetilen bir imparatorluk kurma hayalinin vebalinin onu silah ve para ile destekleyen yabancıların omuzlarında olduğunu ifade eder. 22 Aralık 1956'da Yeni İstanbul'daki Asıl Suçlu yazısında yine Faruk'u söz konusu eden Karay, Nasır darbesinin sorumlusu olarak da Faruk'u gösterir. Ona göre Kral Faruk yönetimindeki rezaletler Abdülnasır darbesine neredeyse meşru bir zemin hazırlamıştır. Her Hitler'in Birkaç Cahmberlain'i Oluyor yazısı 5 Mart 1958'de Yeni İstanbul gazetesinde yayınlanmıştır. Bu yazının konusu Karay'a göre Mısır İhtilali'ni insanlara sempatik gösteren General Necib'in ortadan kayboluşu üzerine yazılmıştır. Albay Cemal Abdülnasır, 25 Şubat 1954'te Necib'i devirip bir villaya hapsetmiştir (Bardakçı, 2011). General Necib'in Sudanlı oluşu nedeniyle hapsedilmesinin Sudan'ın Mısır'a katılmasına engel olduğunu söyleyerek bu durumun 


\section{F.Ü. Sosyal Bilimler Dergisi 2018-28/2}

Mısır diktatörünün hayalindeki Nil Vadisi'nin tamamına sahip olma hevesini de engellediğini belirtir.

Karay'ın 1959'da Irak'ın Bağdat Paktı'ndan ayrılmasını anlatan Soğukkanlıllktan Ayrllmayalım, Biz Neler Gördük! yazısı bu ayrılığın sorumluluğunu Amerika'ya ve Mısır diktatörlügünün sebebi olarak gördüğü son Kral Faruk'a yükler.

Yeni İstanbul gazetesinde 24 Temmuz 1958'de yayınlanan Osmanl ve Avusturya Imparatorluklarının Tasfiyesi Hatası yazısında, I. Dünya Savaşı sonrasında Ortadoğu'nun durumu tartış1ıı. Batı'nın Ortadoğu hesaplarının da tutmayışıyla uzun bir kaos yaşayan Ortadoğu'nun Osmanlı'nın yıkılmamış olması durumunda bugünkü halinden daha iyi bir durumda olacağ vurgulanır. Bu yazıdan bir gün sonra aynı gazetedeki Çölde Bir Devlet Bütçesine Denk Bir Gülistan yazısında ise petrol gelirlerini "görgüsüzce" ve müsrifçe harcayan Suudlardan ve Irak yöneticilerinden bahsedilir. Cenup Komşularımızın Durumları Hakkında ve Krallı da Bir Nevi Karaborsacılık mı Olmuş yazıları, Karay'ın bu dönemde Ortadoğu ile ilgili yazdığı son yazılardır. İlk yazı Ortadoğu'nun coğrafi, sosyolojik ve ekonomik yapısı hakkında bir hülasa mahiyetindedir. İkinci yazı ise Irak üzerinden krallık kavramının kapitalizmle uzlaşısı sonrasında ortaya çıkan zengin diktatörlerin eleştirisi olarak değerlendirilebilecek bir yazıdır.

\section{Sonuç}

Refik Halid Karay, Türkiye’ye geldiği 1938 yılından itibaren gazetelerde yazdığg köşe yazıları ile köşe yazısı konusundaki ustalığını sergileyerek kendine ait özgün tavır oluşturmuş bir yazardır. Kısalık, vuruculuk, akıcılık ve bahsedilen kavramlara hâkimiyet noktasında oldukça başarılı bir köşe yazarı olan Karay'ın Ortadoğu ile özel bir bağı vardır. Yaklaşık 16 yıl Lübnan ve Suriye'de kalan Karay, Ortadoğu'nun sosyal ve siyasi yapısı hakkında sürgünlük yıllarında derin gözlem ve saptamalarda bulunmuştur. Bu gözlemlerin Osmanlı'dan ayrılışından 1950'lerin sonuna kadar Ortadoğu'da gelişen tüm siyasi ve sosyal meselelerin değerlendirilmesinde Karay için çok önemli bir katkı sağladığını söylemek mümkündür. Başlangıçta Suriye'deki manda idaresinin yanlışları ve Ortadoğu ülkelerinin yaşadığı mağduriyetler üzerinden ilerleyen yazılar, Ortadoğu'nun emperyalist politikalarla bağlantılı gelişen Arap milliyetçiliği politikalarına dönüşü üzerine yeni bir mecra bulur. Bugünkü mevcut sosyal ve siyasal yapı hakkında geliştirilecek düşüncelerde de Refik Halid Karay'ın yazılarının göz önünde bulundurulması gerekebilir. Edebi açıdan da oldukça başarılı sayılabilecek yazılar, Türkiye'de gazete fikraları konusunda ilgililerine üslup ve içerik açısından yol gösterici mahiyettedir.

Yazılarda 1956 sonrası Suriye ve Mısır'da gelişen yönetim değişiklikleri nedeni ile yaşanan Türkiye-Suriye gerginlikleri Suriye'deki darbeler tarihi ile eşgüdümlü bir biçimde takip edilir. Bu süreçlerin hazırlık aşamasında Suriye'de Hüsnü Zaim iktidarda sadece dört ay kalabilmiş, başka bir darbe ile devrilmiştir. Suriye 1949 'dan 1955 'e kadar art arda darbeler yaşamış ve sekiz cumhurbaşkanı görmüştür. 1949'da devrilip sürgüne giden Şükrü el Kuvvetli 1955 Eylül'ünde yeniden iktidara gelmiştir. Mısır'da 1952'de krallığı devirip devlet başkanı olan Cemal Abdülnasır, o dönemde Arap dünyasını derinden etkilemiş ve "Arap milliyetçiliği" Ortadoğu politikalarının belirleyicisi olmaya başlamıştır. 1956'dan sonra Amerika'nın bölgede etkili olma girişimine destek veren Menderes hükumetinin bu tavrı Suriye ve Türkiye arasındaki ilişkilerde gerilime neden olmuştur. Bu gerilim 1971'e kadar Amerika-Rusya çekişmesi ekseninde devam etmiş̧tir (Bardakç1, 2011). İlişkilerdeki bu bozulmanın Karay'ın yazılarında üslup düzeyinde etkili olduğu gözlemlenebilir. 46-49 yıllarındaki Şükrü el Kuvvetli iktidarının darbe ile devrilmesi ile 1949'da iktidarı ele geçiren Albay (Mareşal) Zaim'in diktatörlüğü, 48'deki Arap İsrail savaşının Suriye üzerindeki etkileri ve tüm bu gelişmeler karşısında Türkiye'nin tutumları yazıların yeni mecrasıdır. Suriye'de 4 aylık Albay Zaim iktidarından sonraki darbeyi yapan Edip Çiçekli'nin de Şükrü El Kuvvetli gibi Türk soyundan geldiğini ifade ediyor olması Karay'ın yazılarından elde edilebilecek ilginç bilgilerdendir. 
Özellikle Mısır-Suriye ittifakı sonrası Karay’ın Ortadoğu ülkelerine bakışında daha mesafeli bir tavır takındığını söylemek mümkündür. Fransız Mandası Altındaki Suriye'nin mazlumluğunun yerini ironik, küçümseyici bir eleştirel tavır alır. Bu dönemde Arapların Türkiye'nin Arap devletlerinin iç meselelerine karıştığı söylemi Karay'ın bu eleştirel bakış açısını destekler mahiyettedir. Türk dış politikasında muhalefetin ve iktidarın ortak hareket edişini Türk demokrasisinin Araplardan farkı olarak düşünen Karay bu durumu olumlu bulur. Karay'ın Suriye karşısındaki muhalif tutumu Türkiye ve Suriye arasındaki kaçakçılık meselesi üzerinden yazdığı 2 yazı ile somut ekonomik bir mecraya taşınır. Suriye'de gelişen sol faaliyetlerde Ermenilerin etkisini içeren Mahzur ve Suriye istikrarsızlığının toplumsal nedenleri üzerine eğilen Efendi Değiştiren yazıları da eleştirel düşüncenin dozunun arttı̆̆ yazılardır. 1956'dan sonra Arap coğrafyasındaki nasyonalizmin Türkiye'ye karşı Lübnan dışındaki tüm Arap devletlerinde görülen suçlayıcı yönelim Mısır, Yemen ve Suriye örnekleri üzerinden Arapsaçı ve Üye Hazretleri yazılarında kullanılır. Bu yazılarda Karay'ın daha önceki temkinli tutumundan Arap milliyetçiliği aleyhinde yüksek ses sesli, liberal ve seküler bir tavır takındığı gözlemlenebilir.

50'li yıllardan sonra Misır'ın Arap politikalarında belirleyici roller edinmesi Karay'ın yazılarında Kral Faruk'tan onun dönemindeki savurganlık ve yolsuzlukların Misır halkını diktatörlere mecbur bırakmasından kaynaklandığını fikriyle ifadesini bulur. Bu süreç Karay'ın Mısır'daki istikrarsızlıktan daha fazla bahsetmesine olanak tanır.

Refik Halid Karay, Ortadoğu'daki yaklaşık on beş yıllık tecrübesini romanları ve gazete yazılarıyla Türk edebiyatına ve fikir dünyasına başarıyla taşımış bir yazardır. Onun Ortadoğu ile ilgili yazılarının değerlendirilmesi edebî nitelikli eserlerinin de sosyal arka planının anlaşılması için bir imkân mahiyetindedir. Karay'ın yazı dünyasında Osmanlı sonrası Türk aydınının geçirdiği fikrî aşamaları da görmek mümkündür.

\section{KAYNAKÇA}

Akşin, Sina, "Turkish-Syrian Relations in the Time of Faisal" (1918-20), Turkish Yearbook of International Relations, Ankara, s. 3-17. 1986

Armaoğlu, Fahir, 20. yy. Siyasi Tarihi, (1914-1995), Alkım Yayınevi, 16.bs., İstanbul, 2007, s. 506.

Bardakçı Murat, “General Necib'i Hatırlar mısınız?” Habertürk Gazetesi, 14.02.2011, http://www.haberturk.com/yazarlar/murat-bardakci/600750-general-necibi-hatirlar-misiniz,

Bardakçı, Murat, "Suriye İşi Eskiden Daha Büyük Dertti 1957'de Neredeyse Savaş Açacaktık" Habertürk Gazetesi, 04.03.2012, http://www.haberturk.com/yazarlar/murat-bardakci/721567-suriye-isi-eskidendaha-buyuk-dertti-1957de-neredeyse-savas-acacaktik

Ebcioğlu, Hikmet Münür, Kendi Yazılarıyla Refik Halid, İstanbul, Semih Lütfi Kitabevi, 1943.

Kanter, M. Fatih, "Refik Halit Karay'ın Gurbet Hikâyelerinde Orta doğu" Uluslararası Mercidabık'tan Günümüze 500 Yılda Orta Doğu Sempozyumu Bildiri Kitabı, s. 245-250.

Kilis, 2018

Karaca, Alaattin, "Refik Halid'in Gözüyle Suriye'de Fransız Mandası", Karar Gazetesi, 19.02.2018 http://www.karar.com/yazarlar/alaattin-karaca/refik-halidin-gozuyle-suriyedeki-fransiz-mandasi-6244

Karay, Refik Halid, Memleket Yazıları-17: Sulhte Cimri Harpte Müsrif, İnkılâp Kitabevi, (Haz. Tuncay Birkan), İstanbul, 2017

Karay, Refik Halid, Yezidin Kızı, İnkılâp Kitabevi, İstanbul, 2016

Meriç, Cemil, “Süleyman Nazif” Jurnal Cilt 2, İletişim Yayınları, İstanbul, 1998.

Okay, M. Orhan, "Refik Halid Karay ”,Türk Diyanet Vakfi İslam Ansiklopedisi, c. 24, İstanbul, 2001.

Özbalcı, Mustafa, "Hayatının ve Sanatının Ana Çizgileriyle Refik Halid Karay" Ondokuz Mayıs Üniversitesi Eğitim Fakültesi Dergisi, C.3, 1988 
Özbalcı, Mustafa, "Hayatının ve Sanatının Ana Çizgileriyle Refik Halid Karay" On Dokuz Mayıs Üniversitesi Eğitim Fakültesi Dergisi., S.3, s.75-91, 1988, Samsun.

Öztürkci, Alparslan, “Soğuk Savaş'ın 1950'li Yıllarda Orta Doğu'da Yaşanan Askeri Darbelere Etkileri” Çağdaş Türkiye Tarihi Araştırmaları Dergisi Journal Of Modern Turkish History Studies XVII/34 (2017-Bahar/Spring), ss. 373-394.

Soran, Şükür, "İslam Coğrafyasında Değiş̧im ve Demokrasi Sorunu: Mısır”, Avrasya Dosyası, Cilt 11, Sayı 3, 2005.

Törenek, Mehmet, "Bir Dil Ustası: Refik Halid Karay: Üslubuna Dair Bazı Dikkatler” Atatürk Üniversitesi Edebiyat Fakültesi Sosyal Bilimler Dergisi, Sayı/Number 51, Aralık/December 2013, 159-174.

Ünal, Yenal, Yakın Dönem Türk Tarihinde Refik Halid Karay, Yeditepe Yay. İstanbul, 2013.

Yılmaz, Hadiye, "Mustafa Kemal Paşa-Emir Faysal Anlaşması ve Milli Mücadele Döneminde Suriye ve Irak", CTAD, Y1l 10, Sayı 20, (Güz, 2014),s. 289-306.

Yılmaz, Hadiye, "Mustafa Kemal Paşa-Emir Faysal Anlaşması ve Milli Mücadele Döneminde Suriye ve Irak", CTAD, Y1l 10, Sayı 20, (Güz, 2014),s. 289-306 